\title{
Lipstick and Logarithms: Gender, Institutional Context, and Representative Bureaucracy
}

\author{
LAEL R. KEISER A ND VICKY M. WILKINS University of Missouri-Columbia
}

KENNETH J.MEIER Texas A\&M University

CATHERINE A. HOLLA ND University of Missouri-Columbia

\begin{abstract}
A
ccording to the theory of representative bureaucracy, passive representation among public employees will lead to active representation in bureaucratic outputs. E xisting research demonstrates that the link between passive and active representation exists for race but not for sex. Past research on this topic has not, however, taken into account the contextual environment that affects whether sex will translate into gender and lead to active representation in the bureaucracy. In this paper, we create a framework that specifies the conditions that affect whether passive representation results in active representation for sex and then test this framework using the case of education. We find that passive representation of women in education leads to active representation and that the institutional context affects the extent to which this link between passive and active representation occurs.
\end{abstract}

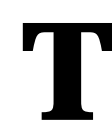
he women's movement has long sought to increase the number of women in leadership positions within government organizations. A $n$ assumption behind this goal is that increased access to positions of power (passive representation) will result in policies that improve the lives other women outside the organization (active representation). Is this assumption valid? Little empirical research exists that explores whether increasing the number of women in an organization affects the policy outputs of the organization. What little research there is shows no link between passive and active representation for gender (H indera 1993; Selden 1997).

In this article, we create a theoretical framework that identifies the conditions under which gender diversity has a substantive effect on organizational outputs and tests whether the passive representation of women in education affects the performance of female students. Future researchers interested in diversity in other bureaucracies, legislatures, or courts can use this framework to explore whether diversity matters in different organizations and across policy areas.

O ur findings for whether passive representation of women leads to active representation in education has implications for public policies seeking to increase the

Lael R. Keiser is A ssistant Professor, D epartment of Political Science and Truman School of Public A ffairs, $U$ niversity of $M$ issouriColumbia, Columbia, M 065211 (keiserl@missouri.edu).

Vicky M. Wilkinsis a PhD candidate in the D epartment of Political Science, U niversity of M issouri-Columbia, Columbia, M O 65211 (vmw9aa@missouri.edu).

K enneth J. Meier is Charles Puryear Professor of L iberal A rts, Sara Lindsey Chair of G overnment and Professor of Political Science, Department of Political Science and George Bush School of Government, Texas A \& M U niversity, College Station, TX 77843 (kmeier@politics.tamu.edu).

Catherine H olland is A ssociate Professor, D epartment of Political Science and Program in Women's Studies, U niversity of M issouriColumbia, Columbia, M 065211 (hollandc@missouri.edu).

A $n$ earlier version of this paper was presented at the A merican Political Science A ssociation M eeting, A ugust 31-September 2, 2002, Washington D.C. A II data and documentation to replicate the analysis is available from the authors. We thank Warren E ller for research assistance. diversity of organizations such as affirmative action. If a link exists between passive and active representation for gender, then diversity, or the lack thereof, has distributive consequences that go beyond the equal opportunity of individual workers.

\section{REPRESENTATIVE BUREAUCRACY}

The literature on representative bureaucracy provides a rich foundation for our research. The premise underlying this research is that a representative bureaucracy is a good to be provided and that a bureaucracy broadly reflective of the interests, opinions, needs, desires, and values of the general public has a legitimate claim to participate in the policy process (Selden 1997). The existing research distinguishes between passive and active representation. Passive representation refers to the bureaucracy's demographic representativeness of a larger population (M osher 1982). A ctive representation, in contrast, is defined as bureaucrats' advocacy of their constituents' interests, making policy decisions that benefit a given group among the agency's clientele, often by eliminating discriminatory barriers ( $\mathrm{H}$ indera 1993; M osher 1982). O ur research is concerned with understanding when passive representation leads to active representation for women. We ask, in the language of $\mathrm{H}$ anna Pitkin (1967), When are female bureaucrats merely "standing for" women and when might we expect them to "act for" women?

M ost research on active representation focuses on race and shows that minority bureaucrats frequently implement policies or use their discretion to reduce the disparate treatment minority clients have received historically from various public bureaucracies ( $\mathrm{H}$ indera 1993; M eier et al. 1989; M eier and Stewart 1992; Selden 1997). In contrast, research examining representation and the sex of the bureaucrats is limited and somewhat mixed in its results. The meager research that exists finds that passive representation for women clearly affects individuals within organizations (D uerst-L ahti and Johnson 1990; K elly, H ale, and B urgess 1991) but has not found evidence that passive representation 
results in active representation of women in bureaucratic outputs (Hindera 1993; Selden 1997). In sum, prior research, sparse as it is, indicates that passive representation can lead to active representation for race but not for sex.

\section{SEX, GENDER, AND IDENTIFICATION: FEMINIST THEORY}

We are intrigued by these findings that race is a significantly more important factor than sex in affecting bureaucrats' actions and decisions. Surely sex is no less, if no more, central in shaping individuals' experiences in the world and, hence, in shaping political values. Why, then, would bureaucrats fail to translate passive representation into active representation on the basis of sex? Because representation is not a normal bureaucratic function, we need to know when female bureaucrats are likely to identify as women rather than as agency employees or a myriad of other roles. The central role of identity in representation logically leads us to work in feminist theory.

Feminist theory suggests that part of the answer to our question lies in the complicated relationship among politics, group identity, and sexual difference. A s Simone de Beauvoir (1974, xxii) observed in 1949, "Women do not say 'We," for they lack a distinctive history, culture, or religion that both marks them off as a collective with internal similarities and differentiates them from others of their social class. In many ways, the history of second-wave feminism in the U nited States confirms de B eauvoir's point, for in the very process of

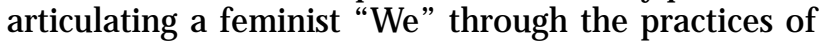
consciousness raising, feminists were confronted with the wide range of markers of difference that distinguish women from one another: race, class, sexuality - the list could go on and on. Could it be that, as some feminists have suggested, women compose a social collective definable only by recourse to a common biological sex (D aly 1978; O 'B rien 1989)?

$D$ efining women according to (supposed) biological similarities that remain constant over time runs afoul, however, of another foundational premise of secondwave feminist thought: the important distinction between sex and gender. Insofar as sex refers simply to the physiological reproductive capacities, gender describes the social and cultural interpretation of sex or, more precisely, the cultural magnification of sexual difference and commensurate suppression of similarities between women and men (Rubin 1975). The concept of gender hel ps feminists challenge limitations that are socially imposed upon women, limitations that are justified by reference to ascriptive characteristics said to follow from biological maleness or femaleness but that differ demonstrably across cultures, social classes, and historical eras. Put differently, gender evokes the social conventions that claim biological sex as their natural origin, marking the difference (for example) between biological femaleness and what counts as feminine in any given time or place. If sex is described as a binary variable (male or female), gender is more accurately thought of as designating a limitless range of possible interpretations of sex that coexist within a given society. ${ }^{1}$

\section{SEX, GENDER, AND INSTITUTIONS}

O ur examination of feminist theory convinces us that the classic social scientists' variable of "sex," crucial as it is to any inquiry measuring the social distinctions between women and men, is simply not nuanced enough to capture fully the complexity of gender. $G$ ender, not sex, is what matters for the purposes of social research (D uerst-L ahti and K elly 1995), for it is the considerably more complicated concept of gender that tracks the political-institutional meanings that make "sex" socially relevant. By extracting "sex" from gender to distinguish female from male, scholars dispense with precisely what makes gender important to social science research-social meaning-and endow sexual difference with a constant and invariant quality that much feminist thinking about social identification and political action shows to be problematic. of course, this presents something of a problem for social scientists, who, for the time being anyway, may be hard pressed to reconfigure their data so as to encode a schema more complicated than the stark binary, male/female, allows us to imagine. $B$ ut this is not reason enough to abandon the effort to rethink how we treat gender, or processes of identification more generally, in empirical work. Certainly researchers can make data tell a more complex story about gender even when they are limited by the binaries of their data; and we suggest that a large part of that project is entailed in the process of interpreting the data or, more precisely, interpreting data in light of the larger institutional features that shape the circumstances in which bureaucrats exercise discretion and act to affect policy outcomes, in other words, in the ways that female bureaucrats identify as women and translate passive into active representation.

In this respect, some of the conceptual contributions of the new institutionalism are useful; this literature can focus our concern with processes of identification by reference to the possibilities opened and foreclosed by institutions themselves and, thus, help us to hone

\footnotetext{
${ }^{1}$ Butler (1990) complicated this distinction between sex and gender. Exclusive attention to the ways in which men and women are formed through gender socialization left sex itself undertheorized and relatively unproblematized. B utler contends that many feminists continue to assume a more or less symmetrical relationship between sex and gender, even as they insist upon the differences between them. If gender is distinct from sex, she suggests, there is no reason to suppose that gender follows from sex, that is, there is no reason to assume that femininity will attach itself exclusively (or even primarily) to female bodies, or masculinity to male bodies. Calling into question the binary character of both sex and gender, Butler argues that sex is subject to the same historical and cultural forces as gender, with the consequence that sex is itself a gendered category. G ender is quite clearly historical, a property not of bodies but of practices that accrue meaning and gain purchase through a regulated series of repetitions that attain the virtual status of institution. Sex is not prior to gender-it is not the natural foundation from which social forces construct gender-but another product of the same practices that constitute gender, testifying to their institutional power.
} 
in on the institutional contexts in which identification is crystallized, enacted, sustained, contested, and transformed. ${ }^{2}$ Institutions work as "ligatures" that fasten competing and cooperating sites of political analysis (the state, the economy, and civil society) together with relationships among political actors and largescale processes (K atznelson 1997, 103). Political agents, including bureaucrats, are always embedded in institutional milieus; they are both shaped and constrained by the contingencies of context and circumstance (Immergut 1998; Katznelson 1997); and public policy is also influenced by the complex, often competing, dynamics fostered by the interaction of institutions (Orren and Skowronek 1994). Even more significant for our purposes here, institutions shape social actors' cognition by conferring identity - that is, by selecting the factors that are to be considered relevant in making decisions. ${ }^{3}$ A s D ouglas $(1986,59)$ states, "Sameness [read identity] is not a quality that can be recognized in things themselves; it is conferred upon elements within a coherent scheme" worked out by institutions for institutional purposes and political ends.

Social institutions are important sites where sexual difference comes to be defined as salient to social identity, for they are the locations where gendered practices develop and are repeated, adapted, and sometimes transformed. Institutional structure is particularly important in shaping the behavior of individuals who work in bureaucracies because bureaucracies are not generally designed to serve a representative function for a particular clientele group. Institutional structures help to determine the purpose and scope of bureaucrats' work and how much discretion they have in carrying out their tasks. H ierarchy, control of information, standard operating procedures, and roles all work to keep individual behavior in line with the goals of the bureaucracy (Simon 1997). We cannot understand bureaucratic behavior without taking into account the institutions in which the behavior takes place. The power of bureaucracies to constrain individual behavior works against active representation because individuals engaging in an advocacy role within the organization must overcome institutional constraints to identify with clients who share their demographic characteristics (M eier 1993a). Institutional structures in the organization can work to highlight identity with the organization (R omzek 1990) and, in so doing, deemphasize identity based on demographic character-

\footnotetext{
2 In more traditional public administration terms, identity is similar to what organizational theorists termed "role." The multiple and changing identities of an individual bureaucrat are similar to Simon's $(1997,158)$ contention that "an individual can assume a variety of roles when these are evoked by appropriate circumstances, each of which may interact only weakly with the others." See also Brudney et al. 2000.

${ }^{3}$ For example, when an academic department is required to report the demographic distribution of its faculty according sex and race, distinctions of maleness or femaleness, and white or black, become salient. B ut when the same department is contracting with a caterer for its annual retirement banquet, other markers of differencesuch as eating habits that distinguish vegetarians from carnivoresemerge as differences that matter.
}

istics. A ccording to Ferguson (1984, 18), hierarchy and roles in bureaucratic settings cause bureaucrats to de-emphasize their multiple identities and to increase the importance of their identity as members of the organization. N ot surprisingly, research has found that the best predictor of bureaucratic attitudes is the agency for which an individual works, not his/her demographic characteristics (M eier and N igro 1976; M osher 1982).

A Ithough institutional structure plays a large role in constraining the behavior of individuals working within it, bureaucraciescannot completely determine and control individual practices. Even with the power of hierarchy, managers of bureaucracies cannot completely circumscribe their subordinates' activities due to information asymmetry and goal conflict (Brehm and $G$ ates 1997; M oe 1984). I n fact, institutional structures and the individuals who inhabit the institution have a symbiotic relationship. The preferences and attitudes of individual bureaucrats work to shape institutional structures such as standard operating procedures and norms (B arnard 1938; B rudney et al. 2000).

Institutions supply the social context and meaning that marks the distinction between gender and sex. Insofar as a considerable body of feminist research in the social sciences demonstrates that gender plays an important role in shaping individual experience and perspective (Chodorow 1978; G illigan 1982; K eller 1985; Young 1990), it stands to reason that bureaucratic institutions, too, are both the subjects and the objects of gendered practices: I nstitutionsare the products of gendered behavior as well as the environment in which that behavior takes place and is (or can be) transformed.

While feminist scholars contend that gender matters, then, it is important to add that institutions matter as well, for it is within institutions that sex accrues social meaning and, thus, through institutional practices that gender becomes politically salient. Put differently, institutional, and institutionalized, practices constitute gender, and constitute gender as both mutable and malleable, shaping the circumstances in which a subject's political consciousness might crystallize around the question of gender and she might act to promote causes and interests associated with women. In short, attending to institutional contexts can help us develop richer interpretations of data that are otherwise limited by binary coding according to sex. D oing so enables us to develop a more nuanced understanding of how and when gender matters, of how and under what conditions female bureaucrats are likely to translate passive into active representation.

The null finding that there is no link between passive and active representation with respect to gender is flawed because it does not explicitly incorporate the institutional and political context of the bureaucratic experience into empirical analysis. The important question facing us is not necessarily whether passive gender representation leads to active representation, but under what conditionsthislink occurs(Kelly and N ewman 2001)? In what follows we create a template that can be used to identify cases when we should expect passive representation to lead to active representation. 


\section{FACTORS THAT FACILITATE ACTIVE REPRESENTATION FOR GENDER}

B ecause institutional and political contexts matter, we should not expect active representation to occur in the case of gender across all bureaucratic settings. Past empirical tests of representative bureaucracy for sex, however, have paid little attention to identifying the context in which bureaucrats' gender identity plays a prominent role in how they perform their work. ${ }^{4}$ We seek to fill this gap in the literature by creating a framework that will identify cases where active representation is likely to occur and use this framework to generate and test hypotheses concerning the impact of gender representation on the bureaucratic outputs of education bureaucracies.

Two necessary, but not sufficient, conditions exist for active bureaucratic representation to occur. First, bureaucrats must have discretion in how they carry out their jobs. In bureaucracies where most decisions are dictated by rules, bureaucrats have few opportunities to shape outputs to reward a particular group (M eier 1993a). Second, a necessary condition for representative bureaucracy concerns the type of policy the organization produces. R esearchers argue that for representative bureaucracy to occur, the policy issue must be salient to the demographic characteristic in question ( Meier 1993a; Selden 1997). Certain policy outputs are salient to demographic characteristics such as gender, while other issues may not be. This definition does little, however, to help us differentiate the issues that are women's issues from those that are not. ${ }^{5}$

Intuitively we all can identify issues that have been defined as "women's issues." I ntuition does little, however, to help us systematically identify policy issues that foster representative bureaucracy. A s a group, women may have a distinct viewpoint on many policy issues, but they do not always do so. The content of women's issues is fluid and changes over time. It is not a constant (compare D olan 2000 and M eier and Nigro 1976).

The fluid nature of what counts as women's issues makes it difficult, therefore, to identify a priori the issues for which we expect to find representative bureaucracy for gender unless we more clearly specify the necessary conditions for an issue to become gendered. ${ }^{6}$ We argue that a policy area can become gendered (1) because the policy directly benefits women as a class, (2) because the gender of the bureaucrat changes the

\footnotetext{
${ }^{4} \mathrm{R}$ esearchers have begun to focus on the interaction between institutional structure and representative bureaucracy (see K elly and N ewman 2001). Thus far, work in this area has not systematically identified the conditions that are necessary and those that are sufficient for representative bureaucracy for gender to exist.

${ }^{5}$ The terms gender and women are not synonymous. The paucity of representation of women in organizations does not make gender unimportant. O rganizations without female representation are gendered to privilege the masculine. Because, historically, women have not been represented in organizations, gender diversity should give organizations a more "female" orientation. Therefore we are interested in issues salient to women as opposed to men. We refer to these issues as "gendered."

${ }^{6} \mathrm{E}$ ven though both men and women have gender, by "gendered" we mean made more relevant to women.
}

client-bureaucrat relationship, or (3) because the issue has been defined as a women's issue through the political process. ${ }^{7}$

The most straightforward way to identify a women's issue is to determine whether the policy directly benefits women as a group as distinct from men. Policiessuch as equal pay and funding for women's health directly benefit women as a class. A s such, they provide bureaucrats an opportunity to play a representative role by distributing benefits to women or by increasing overall benefits.

The second way of identifying gender-salient issues is by exploring whether the gender of the bureaucrat influences the client-bureaucratic relationship. This is most important in street-level bureaucracies where the interaction between bureaucrat and client is crucial in determining policy outputs. When bureaucrats and clients share the same demographic characteristic, they often share the same life experiences (Thielemann and Stewart 1996). Some life experiences are shared by women and, for the most part, not shared by men. In the case of rape, for example, female victims may feel more comfortable working with female law enforcement bureaucrats, who may be more likely to respond productively and sympathetically.

In addition, women can have distinct perspectives on many policies that benefit not only women, but also children and men (social welfare policies for example). R esearch hasfound that gender matters to broader policy areas that do not benefit women exclusively, such as the use of force in foreign or domestic affairs, income redistribution, and consumer concerns ( $\mathrm{H}$ ale and $\mathrm{K}$ elly 1989). The political process of issue definition is such that an issue may be defined one way during one historical period but take on another meaning at another time in response to the work of social movements and interest group pressure (R ochefort and Cobb 1994). For example, in industrialized nations, certain kinds of policy concerns- pay equity, reproductive rights, domestic violence, child care, etc. - are perceived as women's issues, largely because these have been targeted by feminists as venues where the social construction of gender places women at a distinct disadvantage (in assigning to them primary responsibility for child care, for example) or subjects them to systematic discrimination. Such issues represent only a small portion of public policy matters that might, in different circumstances, come to be viewed as having a distinctive impact on women. ${ }^{8}$ We hypothesize that active representation will occur only in bureaucracies dealing with policy issues that

\footnotetext{
${ }^{7}$ Of course behavior will vary among female bureaucrats. Not all women will take up the role of active representation even when an issue is gendered.

8 Selden's (1997) finding that passive representation does not lead to active representation for women is not surprising given the fact that the issue she studied, housing for farmers, is not a particularly gendered issue. The needs of farmers have not been on the feminist political agenda, nor do gender differences exist in public opinion concerning agricultural policy. Furthermore, the lack of high numbers of single female farmers make it unlikely that a street-level bureaucrat will feel that she can advocate for women by increasing aid to farmers.
} 
directly benefit women as a class, gendered policy issues and issues where the bureaucrats' gender identification changes the client-bureaucrat relationship.

0 ther institutional and contextual factors such as the mission of a given bureaucracy should influence the transfer of passive into active representation. Some bureaucracies create advocacy roles for bureaucrats in keeping with organizational missions (Selden 1997) by socializing individual bureaucrats to adopt organizational goals (M arch and OIson 1994; R omzek 1990; Simon 1947). If the bureaucracy has a mission of assisting a particular group, passive representation should lead seamlessly to active representation. A lthough bureaucrats who do not share the demographic characteristics of their clientele should also act as advocates (Downs 1966), those who do share the demographic characteristic(s) should be easier to incorporate into the agency's goals as a consequence of their common demographic predispositions toward these goals. We hypothesize that although mission is not a necessary condition, passive representation in terms of gender might be expected to lead to active representation when the leaders of the bureaucracy or the bureaucracy's historical mission focus on assisting women. A ctive representation will increase as passive representation increases in agencies with an advocacy mission but will not be as strong in agencies lacking this advocacy mission. ${ }^{9}$

Similar to mission, hierarchy will affect whether female bureaucrats become advocates. Some scholars argue that hierarchy by its very nature precludes representative bureaucracy. They argue that hierarchical organizations depersonalize relationships, making members less likely to identify with a group outside of the organization (Ferguson 1984). A ccording to this line of thinking, hierarchical organizations cannot be feminist organizations (Firestone 1970; Gelb 1986). A ccordingly, we should expect bureaucratic organizations to maintain the status quo even as they increase passive representation. We hypothesize that more hierarchical and centralized organizations will be less likely to link passive and active representation.

A lthough hierarchy in and of itself may weaken the link between passive and active representation, the Weberian view of bureaucracy suggests that the existence of hierarchy per se is less important than the question of who occupies the top of any hierarchy. H ierarchy gives control to those bureaucrats at the top of the organizational structure (Weber 1946). B y this reasoning, when women gain access to upper levels of an organization, they should create an internal environment more conducive to representative advocacy. R esearchers have found that stratification affects representative bureaucracy for race (M eier, Stewart, and E ngland 1989). We hypothesize that as the number of women in su-

\footnotetext{
${ }^{9}$ We believe that the historic lack of mission for advocating for women in the EEOC helps to explain the failure of passive representation to lead to active representation that $\mathrm{H}$ indera (1993) finds in his analysis of EE O C activity in the 1980s. In future research we will explore this further.
}

pervisory positions increases, active representation will increase.

In addition, organizational theorists have argued that a numerical threshold is necessary for passive to be transformed into active representation (M eier 1993b; Thompson 1978). A critical mass may be needed for minorities to take an advocacy role (K anter 1977). This leads to our next hypothesis: O rganizations with a critical mass of women will be more likely to allow for active representation.

Professionalization also influences bureaucratic outputs. Professions compete with the bureaucracy in shaping individual bureaucrats' goals because professionals receive some of their rewards from a group outside of the bureaucracy. I ncorporating professionals into bureaucracies incorporates their values into the bureaucracy (E isner 1991; Hodges and D urant 1989; Meier 2000). If professionals who see advocacy for a particular group as their role dominate a bureaucracy, we should expect bureaucratic outputs to be distributed to benefit that group. Similar to mission, professionalization should affect all bureaucrats, not just female ones. H owever, because women may be more disposed toward engaging in active representation for women due to shared experience, we believe that greater professionalization will facilitate the translation of passive representation into active representation. ${ }^{10}$

This section has hypothesized that seven institutional/contextual factors affect the transformation of passive representation into active representation: discretion, the gendering of a given policy issue, mission/socialization, hierarchy, stratification, critical mass, and professionalization. A Ithough active representation should not occur in any organization without discretion and a gendered policy issue, the influence of other factors will become more or less important depending on the specific organization studied.

\section{THE EMPIRICAL CASE}

O ur neoinstitutional theory of representative bureaucracy and gender links the processes of identification with the representation of clientele. This section describes our empirical test of the theory using schools and educational performance. Looking at education systems, we examine how female math teachers affect female students' math scores and subsequently influence student aspirations. A ny movement from the more general theory to specific tests of the theory will inevitably narrow the range of variation; in some cases, variables will become constants (that is, when a single type of agency is investigated, mission becomes a constant) or their variation will be truncated.

\section{Theoretical Modifications}

For bureaucratic representation to occur, the issue involved must be identified asa gendered one. A mong the

\footnotetext{
${ }^{10}$ Women may be more attracted to professions where advocacy is possible, such as social work or teaching.
} 
most constant gender issues in education is that of math scores. $N$ ationwide, a persistent gender gap exists, with girls scoring lower than boys on math tests (Strauss and Subotnik 1994). Performance on standardized math tests is in turn associated with continuing one's education, especially in fields that emphasize math or mathematical reasoning ( $O$ akes 1990; Wilson and Boldizar 1990). Insofar as identifying an issue as gendered is a necessary environmental condition for representation, the matter of improving girls' math scores meets the standard of benefiting women as a class. B y selecting the same type of agencies (schools) during the same time frame (1995-98), we have turned many of the other factors, including mission, into constants.

Within the organization, a second necessary condition for representative bureaucracy is that the bureaucrats in question have discretion to influence outcomes. This paper focuses on street-level bureaucrats: teachers, both female teachers in general and female math teachers in particular. The normal principal (in both senses of the term)-agent relationship provides greater advantages to the agent (i.e., the teacher) than in most other organizations. School systems vest a great deal of autonomy in these street-level personnel who come to the organization as trained professionals. A dministrators only rarely visit individual classrooms and, thus, do not closely monitor the interactions between teacher and student. A dministrative control is limited to issues such as textbooks used, whether lesson plans were filed, and access to instructional resources. While these are important factors, they have only modest effects on how a teacher conducts a class.

With this discretion female teachers could affect the math grades of female students in one of four ways. ${ }^{11}$ First, female teachers aware of the math gap might spend additional time with and generate more positive reinforcement for girls when teaching math. Second, girls who do not have a female math teacher could still identify with one as a role model; this identification could result in a greater effort to succeed in math classes. Third, nonmath teachers might facilitate learning by encouraging students who run into difficulty. A Ithough math teachers are in a better position to provide this encouragement, a student might identify more closely with another teacher with a different specialization. This might be specific and linked to math classes or general and linked to overall aspirations. Some of this influence could work through an informal advising process, or might require no personal contact at all. Fourth, female teachers may be more likely than male teachers to press schools to adopt policies that will encourage girls in fields where they have historically underperformed. A Ithough there is evidence that both male and female teachers call on boys more often, allow boys to dominate classroom discussion, push boys for more information, and expect more from male students (Campbell 1991; Fennema and L eder 1990; Sadker and Sadker 1994), there is evidence that in math and sci-

11 There is a fifth possibility. B ecause schools operate in a segmented labor market, female math teachers might simply be better teachers (see M eier, W rinkle, and Polinard 1999). ence classrooms female teachers act as role models, enhance female students' performance, and warm the "chilly climate" (A ngrist and A Imquist 1975; R othstein 1995; Stake and G ranger 1978). O nly one of these four methods of influence requires that an individual student come into contact with a specific math teacher in a classroom; the other three processes can work throughout the organization. This diffuseness of impact means that it must be studied at the organizational rather than the individual level..$^{12} \mathrm{~A}$ ccordingly, schools serve as the units of analysis.

Within the organization, two of our institutional variables remain relevant-stratification and hierarchy; the other three are essentially constant across organizations- professionalization and socializationor operate at well above minimum levels-critical mass. $\mathrm{H}$ ierarchically, school systems are extremely flat organizations with discretion vested in street-level personnel. D espite the general flat structure, school districts vary, with some being more decentralized. O ur measure of decentralization is the span of control at the street level, that is, the ratio of the number of teachers to the total number of administrators in the organization. As this variable increases, administrators supervise more teachers, with the logical result that the time available to supervise any one teacher will decline. The mean span is 14 , with a standard deviation of five.

D espite the preference for flat organizational forms, school districts are highly stratified by sex and can be considered classic glass-ceiling organizations. Fully $75 \%$ of teachers in Texas schools are female, but only $27 \%$ of supervisors (principals, assistant principals, and assistant superintendents) and only $8.4 \%$ of superintendents are. These data provide us with a measure of stratification-the percentage of female administrators.

The concept of a critical mass plays a role when any group has limited access to the organization (see K anter 1977; M eier 1993b). B oth female teachers (75\%) and female math teachers $(68 \%)$ constitute a majority of their classification. These figures should be well above what constitutes a critical mass, thus rendering the concept inapplicable for teachers (but not for administrators, see below).

In general terms, both professionalization and socialization should be relatively similar across these organizations. Teachers have a common educational background, and they serve a general instructional role within the organization. Individual schools of education might make a teacher more aware of gender issues, and some schools might encourage the development of a representation role; however, data on these factors are not available. In general, the professionalization and socialization of individuals across these organizations should be more similar than different.

\footnotetext{
$\overline{12}$ A nalysis at the individual level might also miss influences that persist through time. If the impact of an individual teacher persists, then studies conducted in later years are unlikely to capture that influence.
} 


\section{The Texas Case}

O ur specific case is 607 Texas high schools from 1995 to 1998. Because many of the data exist only at the district level, we were able to move our unit of analysis to the school level by restricting the analysis to single high school districts (we replicated this analysis with data at the district level and found similar results). Except for the eighth grade math test, all data were measured at the high school level. The Texas case provides an ideal setting for our study for two reasons. First, Texas has statewide standardized tests and an elaborate database that permits analysis by sex. Second, the Texas set of schools is extremely diverse in terms of race, ethnicity, resources, urban location, and other factors that affect education performance. The diversity of these schools suggests that findings from Texas should also apply to other educational systems as well as to organizations with similar characteristics (highly professionalized organizations with discretion vested in street-level bureaucrats). If Texas differs from other states, it is because educational performance has consistently been a salient issue for the past 15 years and because expenditures have increased more rapidly in Texas than in the nation as a whole.

\section{Dependent Variables}

Texas requires standardized tests of all students in grades $3,5,6,7$, and 8 as well as an exit exam. O ur first dependent variables are the percentage of female students who pass the math exams in grade 8 and the exit exam. The literature suggests that math scores diverge only in junior and senior high when girls face the choice between lipstick and logarithms (Fennema and Sherman 1977; M eece and Parsons 1982; O akes 1990; Strauss and Subotnik 1994). In Texas, boys' and girls' math scores are essentially the same in grades 3 through 8 , but boys' pass rates exceed girls' by 4.1 percentage points on the exit exam.

Performance on standardized tests is a hurdle along the way to educational achievement. Students who perform poorly on such exams may also perform poorly on others or might reduce their overall educational aspirations. To investigate these phenomena in the context of representative bureaucracy, four other dependent variables are examined-average SA T scores, average ACT scores, the percentage of students who score above 1110 on the SAT or its equivalent on the A CT, and the successful completion of advanced placement exams (for which college credit is given). $G$ irls in Texas score higher than boys on the A CT (16.8 vs. 15.2) and are more likely to pass advanced placement classes (15.7\% vs. $14.1 \%$ ) but score well below boys on SAT exams ( 933 vs. 962) and are less likely to break the 1,110 standard (16.8\% vs. $18.3 \%)$. The lower SA T scores are not a function of more girls taking the test; correlations between the number of test takers and the average scores approach 0 when more than $30 \%$ of students take the exam. The correlation in this data set where $46 \%$ of students take the SAT is only 0.08 , and that disappears with a control for poverty.

\section{Control Variables}

In addition to the key independent variables (female math teachers or female teachers, hierarchy and stratification), two sets of controls are used-one set for the task difficulty facing the organization and the other for organizational resources. Task difficulty reflects the truism that some students are easier to educate than others. The literature consistently finds that poverty and race are correlated with greater education problems (J encks and Phillips 1998). Poverty and race are associated both with a lack of educational resources in the home and with other factors (e.g., single-family households) that affect student learning. The three specific measures are the percentage of black students, the percentage of L atino students, and the percentage of poor students (measured as students eligible for free school lunch programs). E ach of these control variables should be negatively related to student performance.

The relationship between resources and student performance is controversial ( $H$ anushek 1996; $H$ edges and $G$ reenwald 1996). R ecent research using well-crafted longitudinal data sets and well-designed experiments, however, generally shows that additional resources are associated with higher student performance (Evans, M urray, and Schwab 1997; Wenglinsky 1997). Two measures of resourcesare included - average teacher salary and average class size. Teacher salaries should be positively related to student performance, and class size should be negatively related to performance. ${ }^{13}$

Because our data are pooled (four years and 607 schools), we also include a set of control variables to deal with the time series aspect of the data set. D ummy variables for individual years were included in each equation. These dummy variables were always jointly significant, reflecting the overall positive trends in the student performance. To deal with the other source of problems related to pools, we assessed the cross sections of each equation for heteroscedasticity. L evels of heteroscedasticity were modest, and using robust standard errors had little impact on the findings presented here.

\section{FINDINGS}

The two regressions for girls' math scores are given in Table 1. The results are consistent with expectations. Female math teachers are positively associated with girls' math scores in grade 8 and on the exit exam. For grades 3,5 , and 6 the relationships are not statistically different from zero (results not shown). These findings are consistent with the literature that finds that sex differences in math performance do not arise until junior high. A t lower grade levels where there are no sex differences, the sex of math teachers appears to be irrelevant. ${ }^{14}$ In junior high and senior high, female

\footnotetext{
${ }^{13}$ Wealso estimated these equationsusing median family income and percentage of the population living in poverty. N either variable was statistically significant in the presence of the other control variables. Including these variables did not affect the other relationships found. 14 The lack of relationship at the elementary levels makes sense also given the key independent variable- math teachers. $M$ ath teachers
} 


\begin{tabular}{|c|c|c|c|c|c|c|}
\hline \multirow[b]{2}{*}{ Independent Variable } & \multicolumn{3}{|c|}{ Exit Exam } & \multicolumn{3}{|c|}{ Grade 8} \\
\hline & Slope & Error & $t$ & Slope & Error & $t$ \\
\hline Female math teachers & 0.055 & 0.013 & 4.09 & 0.053 & 0.013 & 4.08 \\
\hline Black student percentage & -0.288 & 0.027 & 10.78 & -0.272 & 0.026 & 10.56 \\
\hline Latino student percentage & -0.115 & 0.018 & 6.47 & -0.105 & 0.017 & 6.12 \\
\hline Low-income student percentage & -0.142 & 0.026 & 5.51 & -0.205 & 0.025 & 8.19 \\
\hline Teachers' salaries $(000)$ & 0.768 & 0.137 & 5.62 & 0.747 & 0.131 & 5.69 \\
\hline Class size & -1.053 & 0.147 & 7.17 & -0.971 & 0.142 & 6.86 \\
\hline Adjusted $R^{2}$ & .35 & & & .51 & & \\
\hline$F$ & 145.20 & & & 281.62 & & \\
\hline SE & 12.69 & & & 12.27 & & \\
\hline$N$ of cases & 2,414 & & & 2,427 & & \\
\hline
\end{tabular}

math teachers are associated with higher math scores for girls even when controlling for other factors.

On the math exit exam, a one percentage point increase in female math teachersisassociated with a 0.055 percentage point increase in the girls' pass rate, all other things being equal. While this appears to be a relatively modest relationship, in fact, a one-standard deviation change in the percentage of female math teachers is associated with a change equivalent to $25 \%$ of the gap between boys' and girls' math scores. While the sex of math teachers is clearly not the most important factor in math education, reductions of this size would be substantively important and well worth pursuing. ${ }^{15}$ The control variables' relationships are all consistent with expectations.

R epresentation is a process that should be affected by institutional factors. In this case, both hierarchy and stratification vary. Female math teachers should be most likely to act in ways to benefit female students in organizations with low levels of hierarchy and high numbers of female administrators.

Table 2 examines the math exit exam and splits our districts according to the key institutional variables (we split the data rather than use interaction effects to avoid the massive collinearity generated by interac-

are a certified designation that applies only to secondary school teachers. E lementary school teachers are certified only as elementary school teachers unless they have a specialization such as special education or bilingual education. $M$ ath is not a designated elementary certification in Texas. In short, math teachers are unlikely to affect math scores when there are no "math" teachers.

${ }^{15}$ The $25 \%$ figure would hold if boys were not affected by having a woman math teacher. In fact, boys' scores are also improved by having a woman math teacher but not as much as girls' scores are. This means that the gap would not close this quickly. The illustration is provided as a way of judging the substantive size of the impact, not on closing the gap per se. The impact of female math teachers on boys' scores is an important issue substantively and theoretically. When boys' scores on any of the indicators are included in these models, the results are weaker but generally hold up. We present the models without boys' scores because our theory contends that representation will generate benefits for the represented clientele; it does not argue that the represented will benefit more than other clientele. tion terms). R egressions are run for hierarchical and nonhierarchical organizations (span of control greater than 14) and for organizations with more and less female administrators ( $25 \%$ cut point). ${ }^{16}$ O ur institutional hypothesis is that the impact of female math teachers should increase (that is, the regression coefficient should increase) in flat organizations and in organizations with more female administrators. The results are mixed. The teachers' slope increases for flat organizations, but the difference is not statistically significant. For female administrators the relationship is statistically significant, but the difference is in the wrong direction. These mixed findings may be explained by the nature of math instruction, which is highly specific and rife with discretion. O rganizations may be likely to find it difficult to modify a process that is characterized by extremely high levels of information asymmetry and few opportunities for observation.

A Ithough math exams are a relatively narrow slice of public school curricula, they have long-term implications for building human capital. Table 3 relates math exit exams to average SA T scores (the verbal and math total; individual tests are not available). Several findings are relevant. First, math exit scores are positively correlated with SAT scores; all things equal, a onepercentile increase in the pass rate is associated with a 0.95 point increase on the SAT (about 15.8 points for a one-standard deviation change). Second, math teachers affect SAT scores only indirectly via their impact on the math exam. Third, female teachers in general, however, are associated with a substantial increase in female SA T scores; a one-percentile increase in female teachers is associated with an increase of 2.0 points on the SAT (about 17 points for a one standard deviation change), all other things equal.

The results in Table 3 suggest a slight change in focus to female teachers in general and to indicators of

\footnotetext{
${ }^{16}$ We use $25 \%$ as a threshold effect for administrators based on M eier's (1993b) empirical estimates for race rather than Kanter's (1977) theoretical estimate of $15 \%$. The use of $25 \%$ also divides the sample more evenly.
} 


\section{TABLE 2. Female Math Teachers and Girls' Math Scores: Dependent Variable $=$ Percentage of Girls Passing the Math Exit Exam}

\begin{tabular}{|c|c|c|c|c|}
\hline \multirow[b]{2}{*}{ Independent Variable } & \multicolumn{2}{|c|}{ Hierarchy } & \multicolumn{2}{|c|}{$\begin{array}{c}\text { Stratification, } \\
\text { Female Managers }\end{array}$} \\
\hline & Low & High & Few & Many \\
\hline Female math teachers & $\begin{array}{l}0.065 \\
(3.34)\end{array}$ & $\begin{array}{c}0.052 \\
(2.69)\end{array}$ & $\begin{array}{c}0.078 \\
(3.91)\end{array}$ & $\begin{array}{c}0.025 \\
(1.24)\end{array}$ \\
\hline Black student percentage & $\begin{array}{c}-0.249 \\
(7.90)\end{array}$ & $\begin{array}{c}-0.316 \\
(6.81)\end{array}$ & $\begin{array}{r}-0.307 \\
(6.20)\end{array}$ & $\begin{array}{c}-0.258 \\
(7.94)\end{array}$ \\
\hline Latino student percentage & $\begin{array}{c}-0.085 \\
(3.84)\end{array}$ & $\begin{array}{c}-0.128 \\
(4.44)\end{array}$ & $\begin{array}{c}-0.123 \\
(3.85)\end{array}$ & $\begin{array}{c}-0.099 \\
(4.32)\end{array}$ \\
\hline Low-income student percentage & $\begin{array}{c}-0.184 \\
(5.92)\end{array}$ & $\begin{array}{c}-0.115 \\
(2.64)\end{array}$ & $\begin{array}{c}-0.119 \\
(2.45)\end{array}$ & $\begin{array}{c}-0.178 \\
(5.57)\end{array}$ \\
\hline Teachers' salaries $(000)$ & $\begin{array}{l}0.621 \\
(3.49)\end{array}$ & $\begin{array}{l}0.988 \\
(4.59)\end{array}$ & $\begin{array}{l}0.909 \\
(3.93)\end{array}$ & $\begin{array}{l}0.489 \\
(2.62)\end{array}$ \\
\hline Class size & $\begin{array}{c}-1.135 \\
(5.90)\end{array}$ & $\begin{array}{c}-0.693 \\
(2.74)\end{array}$ & $\begin{array}{c}-1.069 \\
(4.18)\end{array}$ & $\begin{array}{r}-0.897 \\
(4.48)\end{array}$ \\
\hline Adjusted $R^{2}$ & .44 & .28 & .31 & .40 \\
\hline$F$ & 114.50 & 45.26 & 50.04 & 87.53 \\
\hline SE & 10.88 & 14.57 & 13.45 & 11.78 \\
\hline$N$ of cases & 1,300 & 1,075 & 983 & 1,153 \\
\hline
\end{tabular}

TABLE 3. Specific Versus General Impacts: Math Teachers and Other Teachers: Dependent Variable $=$ Girls' SAT Exam Scores

\begin{tabular}{lccc}
\hline Independent Variable & Slope & Error & $t$ Score \\
\hline Female math teachers & -0.007 & 0.106 & -0.06 \\
Female teachers & 2.003 & 0.384 & $5.22^{*}$ \\
Math exit exam scores & 0.952 & 0.136 & $6.99^{*}$ \\
Black student percentage & 0.070 & 0.162 & 0.43 \\
Latino student percentage & -0.045 & 0.112 & 0.40 \\
Low-income student percentage & -1.239 & 0.163 & $7.62^{*}$ \\
Teachers' salaries (000) & 5.172 & 0.862 & $5.96^{*}$ \\
Class size & 1.104 & 1.010 & 1.09 \\
& & & \\
Adjusted $R^{2}$ & .50 & & \\
$F$ & 150.09 & 62.77 & \\
SE & 1,657 & & \\
$\quad N$ of cases & &
\end{tabular}

college aspirations. Because the influence of female teachers is likely to be diffused through out the organization, the institutional factors in our theoryhierarchy and stratification-in this case, are also more likely to come into play. The next two tables examine SA T scores, A CT scores, high exam scores, and passing advanced placement exams and how the relationships between these variables and female teachers are structured by hierarchy and stratification. A gain, our working hypothesis is that the influence of female teachers will be enhanced in decentralized organizations and organizations with women in positions of administrative authority.

Table 4 shows how hierarchy interacts with female teachers to affect female student performance. The second column of the table shows that female teachers are positively associated with outcomesfor female students on all four indicators. With regard to the interaction with structure, our hypothesis is that women teachers will have a greater impact in relatively flat organizations (those with a span of control over more than 14). In flatter organizations, a one-percentage point increase in female faculty is associated with a 3.36-point gain on the SAT, substantially more than the corresponding $0.85-$ point gain for more hierarchical organizations. Similarly for ACT scores, the slope for female teachers is more than three times higher in flat organizations than in the others. A t the high end of the scale, that is, scores above 1,110 on the SA T or its A CT equivalent, a onepercentile increase in female teachers correlates with a 0.37-percentage point increase in high-performing students in flat organizations; in other organizations, the relationship is essentially zero. Finally, the strongest comparison exists for advanced placement classes. A 


\section{TABLE 4. Institutions and Representative Bureaucracy: The Case of Hierarchy}

\begin{tabular}{|c|c|c|c|c|c|c|}
\hline \multirow[b]{2}{*}{ Dependent Variable } & \multicolumn{2}{|c|}{ All Schools } & \multicolumn{2}{|c|}{ Hierarchy } & \multirow[b]{2}{*}{$t$ Score $^{a}$} & \multirow[b]{2}{*}{ Probability } \\
\hline & Slope & $t$ Score & Low Slope & High Slope & & \\
\hline SAT scores & 2.215 & 6.38 & 3.359 & 0.848 & 5.46 & $<0.001$ \\
\hline $\begin{array}{l}\text { ACT scores } \\
\text { Above criterion }\end{array}$ & 0.061 & 2.25 & 0.091 & 0.025 & 1.98 & .024 \\
\hline$(1,100$ SAT equivalent) & 0.144 & 3.22 & 0.373 & -0.033 & 6.62 & $<0.001$ \\
\hline Advanced placement & 0.504 & 5.88 & 0.892 & 0.015 & 10.23 & $<0.001$ \\
\hline
\end{tabular}

TABLE 5. Institutions and Representative Bureaucracy: The Case of Stratification

\begin{tabular}{|c|c|c|c|c|c|c|}
\hline \multirow[b]{2}{*}{ Dependent Variable } & \multicolumn{2}{|c|}{ All Schools } & \multicolumn{2}{|c|}{ Women Managers } & \multirow[b]{2}{*}{$t$ Test } & \multirow[b]{2}{*}{ Probability } \\
\hline & Slope & $t$ Score & $20 \%+$ & $<20 \%$ & & \\
\hline SAT scores & 2.215 & 6.38 & 2.745 & 1.801 & 1.91 & .028 \\
\hline ACT scores & 0.061 & 2.25 & 0.088 & 0.032 & 1.40 & .081 \\
\hline Above criterion & & & & & & \\
\hline$(1,110$ SAT equivalent) & 0.144 & 3.22 & 0.202 & 0.043 & 2.46 & .006 \\
\hline Advanced placement & 0.504 & 5.88 & 0.665 & 0.120 & 3.68 & $<0.001$ \\
\hline
\end{tabular}

one-percentage point increase in female teachers is linked to 0.89 percentage point more female students taking and passing advanced placement examsin flat organizations; again, in other organizations the relationship is essentially zero. A II four differences between the sets of slopes are statistically significant at the 0.05 level; in every case, active representative is greater in less hierarchical organizations.

In Table 5 the relationship between high levels of female administrators and the representation function of female teachers is probed. The hypothesis is that a larger number of female administrators should permit female teachers to be more active representatives for their female students. In every case, the slope coefficient for female teachers is larger in organizations with more than $25 \%$ female administrators than it is in the other organizations. In three of the four cases (the exception is ACT scores), the relationship is significant at the .05 level (one tail test). In the ACT case, the difference between the two coefficients barely misses statistical significance.

$O$ verall our findings in Tables 4 and 5 show eight of the eight relationships to be consistent with the institutional hypotheses about representative bureaucracy (seven of eight if one counts only statistically significant differences). If there were no relationships between structure and representation, the probability that we could get eight of eight relationships in a predicted direction is less than .004 (for seven or more of eight the probability is .035). ${ }^{17}$

\footnotetext{
${ }_{17}$ Calculated as a binomial probability distribution of eight successes in eight trials with a probability of .5 .
}

\section{CONCLUSION}

A ccording to our framework, public education meets the necessary conditions for the transfer of passive representation to active representation for women. Consistent with our theory, passive representation does lead to active representation for gender in public education. A $n$ increase in passive representation for female math teachers and for female teachers in general correlates with educational benefits for girls. The level of passive representation for women in the bureaucracy has consequences for the policy benefits the bureaucracy produces for women. In contrast to past research, our findingssuggest that the link between passive and active representation can exist for gender, as well as race. These findings support the assertion that the benefits of diversity go beyond providing equal opportunity to individuals. Some have critiqued policies such as affirmative action as providing benefits solely to middle-class women (G illiam 1995). O ur findings suggest, however, that increasing the diversity of bureaucratic organizations for sex has implications for female clients of the bureaucracy, many of whom are not middle-class.

Our findings also support our contention that institutional context affects whether passive representation will lead to active representation. The findings show consistent support that stratification and hierarchy play an important role. In schools with more female administrators, female teachers were associated with higher A CT, SAT, and advanced placement rates for girls. For hierarchy, the representative process also worked better for girls in less hierarchical organizations. Clearly, stratification and hierarchy are important institutional variables that affect whether passive 
representation will lead to active representation. For those seeking to increase active representation on the basis of gender, attention must be paid to not only increasing overall passive representation but also the structure of the organization and the representation at upper levels of the organization. Institutional barriers that create glass ceilings for women have policy consequences that go beyond the lack of opportunity for individual women.

This study is the first to find that passive bureaucratic representation translates into active representation for women, and thus it sheds some light on an old puzzle, namely, why previous research has uncovered a strong association between passive and active representation where race is concerned but no relationship at all where gender is the object of scrutiny. R ace and gender are of interest to students of representative bureaucracy precisely insofar as they accrue political meaning within institutions. While scholars in the field have long been attentive to the ways in which race is institutionally defined, they have been less careful in their considerations of gender. ${ }^{18}$ Scholars who rely exclusively on "sex" - that is, on data encoded according to the binary "male/female" - without accounting for the ways in which these designations acquire meaning within institutions (and public life more generally) miss precisely what it is that makes gender political. This is to say that they miss the very factors that are likely to move women working within bureaucracies to act to reduce institutionalized biases against women, individually and collectively. We attribute our unique positive results to our efforts to wed our neoinstitutional framework with the insights of feminist theory. This study is, however, only the first step in a reformulation of the theory of representative bureaucracy and women.

To explore fully whether passive representation leads to active representation for women in the bureaucracy, researchers must examine a variety of cases. We hope that the framework presented in this analysis will provide guidance in terms of the cases where we should look for gender representation. Thusfar, little attention has been paid to identifying cases where, theoretically, gender representation should occur and where it should not. The case of education suggests that passive representation can lead to active representation for gender. Future research is needed, however, to verify whether this will occur across policy areas that meet our necessary conditions. O nce we select cases where opportunities exist for representative bureaucracy, additional empirical tests can be conducted to determine whether the institutional variables we have identified matter.

\section{REFERENCES}

A ngrist, S. S., and E. M . A Imquist. 1975. Careers and Contingencies: H ow College Women Juggle with $\mathrm{G}$ ender. N ew Y ork: D unellen.

${ }_{18}$ Without explicitly doing so, studies on race and representative bureaucracy have chosen institutions that are conducive to the translation of passive into active representation. 0 ur theory that the institutional context is important applies to both race and sex.
B arnard, Chester. 1938. Functions of the E xecutive. Cambridge, M A : B elnap Press of $\mathrm{H}$ arvard.

B rehm, John, and Scott G ates. 1997. Working, Shirking, and Sabotage: B ureaucratic Response to a D emocratic Public. A nn A rbor: $U$ niversity of $M$ ichigan Press.

B rudney, J effrey L., F. Ted H ebert, and D eil S. W right. 2000. "From O rganizational Values to O rganizational R oles." Journal of Public A dministration Research and Theory 10 (July): 491-512.

B utler, Judith. 1990. G ender Trouble: Feminism and the Subversion of I dentity. N ew York: R outledge.

Campbell, P. 1991. "G irls and M ath: Enough Is known for A ction." Women's E ducation E quity A ct Publishing Center D igest 2: 1-3.

Chodorow, Nancy. 1978. The Reproduction of M othering: Psychoanalysis and the Sociology of $G$ ender. Berkeley: U niversity of California Press.

D aly, M ary. 1978. G ynecology: The M etaethics of Radical Feminism. B oston: B eacon.

de B eauvoir, Simone. 1974. The Second Sex. N ew Y ork: Vintage.

Dolan, Julie. 2000. "A n Empirical A ssessment of Representative Bureaucracy Theory: A Comparison of Federal Budget Priorities A mong Senior Executives and the General Public." Paper presented at the A nnual M eeting of the Midwest Political Science A ssociation.

D ouglas, M ary. 1986. How Institutions Think. Syracuse: Syracuse U niversity Press.

D owns, A nthony. 1966. Inside B ureaucracy. Prospect H eights, IL: Waveland Press.

D uerst-L ahti, Georgia, and Cathy M arie Johnson. 1990. "G ender and Style in B ureaucracy." Women and Politics 10 (4): 67-120.

D uerst-L ahti, G eorgia, and R ita M ae K elly. 1995. "O n G overnance, L eadership, and G ender." In G ender Power, L eadership, and G overnance, eds. Georgia Duerst Lahti and Rita Mae Kelly. Ann A rbor: $U$ niversity of $M$ ichigan Press.

E isner, M ark A llen. 1991. A ntitrust and the Triumph of E conomics. Chapel $\mathrm{H}$ ill: $U$ niversity of $\mathrm{N}$ orth Carolina Press.

Evans, William N., Shelia E. Murray, and Robert M. Schwab. 1997. "Schoolhouses, Courthouses, and Statehouses A fter Serrano." Journal of Policy A nalysis and M anagement 16 (Winter): 10-31.

Fennema, E lizabeth, and G. C. L eder. 1990. M athematics and G ender. $\mathrm{N}$ ew Y ork: Teachers College Press.

Fennema, Elizabeth, and J. Sherman. 1977. "Sex R elated D ifferences in $M$ athematics $A$ chievement, Spatial V isualization and $A f-$ fective Factors." A merican E ducational Research Journal 14 (1): 51-71.

Ferguson, Kathy. 1984. The Feminist Case A gainst Bureaucracy. Philadel phia: Temple U niversity Press.

Firestone, Shulamith. 1970. TheD ialectic of Sex. N ew Y ork: B antam. G elb, Joyce. 1986. "R eview of the Feminist Case A gainst Bureaucracy." Political Science Q uarterly 101 (1): 160-61.

G illiam, D orothy. 1995. "R eaching A cross the R acial D ivide." I n Skin D eep, eds. M arita G olden and Susan R ichards Shreve. N ew York: A nchor B ooks.

Gilligan, Carol. 1982. In a Different Voice: Psychological Theory and Women's D evelopment. Cambridge, M A : H arvard U niversity Press.

H ale, M. M ., and R ita M . K elly. 1989. " G ender, D emocracy, and R epresentative B ureaucracies." In G ender, B ureaucracy, and D emocracy, eds. M. M. Hale and R ita M. K elly. N ew York: G reenwood Press.

H anushek, Eric A. 1996. "School R esources and Student Performance." In D oes M oney M atter? The E ffect of School Resources on Student A chievement and A dult Success, ed. Gary Burtless. Washington, DC: B rookings.

H edges, L arry V., and R ob G reenwald. 1996. "H ave Times Changed? The Relation between School Resources and Student Performance." In D oes M oney M atter? The E ffect of School Resources on Student A chievement and A dult Success, ed. Gary Burtless. Washington, DC: B rookings.

Hindera, John J., 1993. "Representative Bureaucracy: Imprimis E vidence of A ctive R epresentation in the E E O C D istrict O ffice." Social Science Q uarterly 74 ( $M$ arch): 95-108.

H odges, D onald G. and R obert F. D urant. 1989. "The Professional State R evisted: Twixt Scylla and Charybdis?" Public A dministration R eview 49 (September/O ctober): 474-85. 
Immergut, Ellen M. 1998. "The Theoretical Core of the New Institutionalism," Politics \& Society 26 (1): 5-34.

Jencks, Christopher, and M eredith Phillips. 1998. The Black-White Test Score G ap. Washington, D C: B rookings.

$K$ anter, R osabeth M oss. 1977. M en and Women of the Corporation. New York: B asic Books.

K atznelson, Ira. 1997. "Structure and Configuration in Comparative Politics." In Comparative Politics: Rationality, Culture, and Structure, eds. M ark Irving Lichbach and A lan S. Zuckerman. Cambridge: Cambridge $U$ niversity Press.

Keller, E velyn Fox. 1985. Reflections on Gender and Science. New $\mathrm{H}$ aven, $\mathrm{CT}$ : $\mathrm{Y}$ ale $\mathrm{U}$ niversity Press.

K elly, R ita M ae, and M eredith A . N ewman. 2001. "The G endered Bureaucracy: A gency $M$ ission, E quality of $O$ pportunity, and R epresentative B ureaucracies." Women and Politics 22 (3): 1-34.

Kelly, Rita M ae, M ary M. Hale, and Jayne Burgess. 1991. "G ender and $M$ anagerial/L eadership Styles: $A$ Comparison of $A$ rizona Public A dministrators." Women and Politics 11 (2): 19-39.

M arch, James G., and J ohan P. O Isen. 1984. "The N ew Institutionalism: O rganizational Factors in Political L ife." A merican Political Science R eview 78: 734-49.

Meece, J. L., and J. E. Parsons. 1982. "Sex Differences in Math A chievement: Toward a M odel of A cademic Choice." Psychological Bulletin 91: 324-48.

M eier, K enneth J. 1993a. "R epresentative B ureaucracy: A Theoretical and E mpirical Exposition." In Research in Public A dministration, ed. James Perry. G reenwich CT: JA I Press.

M eier, K enneth J. 1993b. "L atinos and R epresentative B ureaucracy: Testing the Thompson and Henderson H ypotheses." J ournal of Public A dministration Research and Theory 3: 393-414.

M eier, K enneth J. 2000. Politics and the B ureaucracy: Policymaking in the Fourth B ranch of G overnment. 4th ed. N ew Y ork: H arcourt College.

M eier, K enneth J., and L. G. Nigro. 1976. "R epresentative B ureaucracy and Policy Preferences: A Study In the A ttitudes of Federal Executives." Public A dministration R eview 36: 458-69.

M eier, K enneth J., and J. Stewart. 1992. "A ctive R epresentation in E ducational Bureaucracies: Policy Impacts." A merican Review of Public A dministration 22: 157-71.

M eier, K enneth J., J oseph Stewart, J r., and R obert E ngland. 1989. Race, Class, and Education. M adison: U niversity of Wisconsin Press.

M eier, K enneth J., R obert D. W rinkle, and J. L . Polinard. 1999. "R epresentative Bureaucracy and Distributional Equity: A ddressing the $\mathrm{H}$ ard Q uestion." J ournal of Politics 61 (4): 1025-39.

M oe, Terry. 1984. "The N ew E conomics of O rganization." A merican Journal of Political Science 28: 739-77.

M osher, Frederick. 1982. D emocracy and the Public Service. New York: Oxford U niversity Press.

O akes, Jeannie. 1990. "O pportunities, A chievement, and Choice: Women and Minority Students in Science and Mathematics." Review of Research in E ducation 16: 153-222.

$\mathrm{O}$ 'B rien, M ary. 1989. Reproducing the World: Essays in Feminist Theory. B oulder, CO : Westview.
O rren, K aren, and Stephen Skowronek. 1994. "B eyond the I conography of Order: Notes for a 'New Institutionalism.'" In The D ynamics of A merican Politics: A pproaches and Interpretations, eds. L awrence C. D odd and Calvin Jillson. B oulder, CO : Westview.

Pitkin, $\mathrm{H}$ annah. 1967. The Concept of R epresentation. B erkeley: U niversity of California Press.

R ochefort, D avid A ., and R oger W. Cobb. 1994. The Politics of Problem D efinition: Shaping the Policy A genda. L awrence: $U$ niversity of $K$ ansas Press.

R omzek, B arbara. 1990. "E mployee Investment and Commitment: The Ties that B ind." Public A dministration Review 50: 374-82.

R othstein, D onna S. 1995. "D o Female Faculty I nfluence Female Students' E ducational and Labor M arket A ttainments?" Industrial and $L$ abor Relations R eview 48 (3): 515-30.

R ubin, Gayle. 1975. "The Traffic in Women: Notes on the 'Political E conomy' of Sex." In Toward an A nthropology of Women, ed. R ayna R. R eiter. N ew Y ork: M onthly R eview.

Sadker, M. P., and D. M. Sadker. 1994. Failing atFairness: H ow A merican Schools Cheat G irls. N ew Y ork: Charles Scribner's Sons.

Selden, Sally Coleman, 1997. The Promise of Representative Bureaucracy: $D$ iversity and R esponsiveness in a G overnment $A$ gency. A rmonk, NY: ME Sharpe.

Simon, Herbert A. 1947. Administrative Behavior: A Study of $D$ ecision- $M$ aking P rocesses in $A$ dministrative $O$ rganizations. N ew York: Free Press.

Simon, Herbert A. 1997. Administrative Behavior: A Study of Decision-Making Processes in Administrative Organizations, 4th ed. New York: Free Press.

Stake, J. E., and C. R. G ranger. 1978. "Same-sex and O pposite Sex Teacher M odel Influences on Science Career Commitment among H igh School Students." J ournal of E ducational Psychology 70 (2): 180-86.

Strauss, S. M ., and R. F. Subotnik.1994. "G ender D ifferences in B ehavior and A chievement." A ssociation for Women in M athematics N ewsletter 24 (3): 12-25.

Thieleman, G regory S., and J oseph Stewart, J r. 1996. "A D emandSide Perspective on the Importance of R epresentative Bureaucracy: A IDS, E thnicity, G ender, and Sexual O rientation." Public A dministration R eview 56 (2): 168-73.

Thompson, Frank. J. 1978. "Civil Servants and the Deprived: SocioPolitical and $\mathrm{O}$ ccupational Explanations of $\mathrm{A}$ ttitudes Toward $\mathrm{M} \mathrm{i}$ nority H iring." A merican Journal of Political Science 22 (M ay): 325-47.

Weber, M ax. 1946. From M ax Weber: Essays in Sociology, trans. H. H. Gerth and C. Wright M ills. N ew York: Oxford U niversity Press.

Wenglinsky, Harold. 1997. H ow E ducation Expenditures Improve Student Performance and H ow They D on't. Princeton, N J : E ducational Testing Service.

Wilson, K . L., and J. P. B oldizar. 1990. “G ender Segregation in H igher $E$ ducation: $E$ ffects of $A$ spirations, $M$ athematics $A$ chievement, and Income." Sociology of E ducation 63 (January): 62-74.

Young, Iris Marion. 1990. Justice and the Politics of Difference. Princeton, NJ : Princeton U niversity Press. 